\title{
Rare Metals Mineralization in Pegmatite at Abu Rusheid Area, South Eastern Desert, Egypt
}

\author{
Ibrahim, M.E ${ }^{1}$., Saleh,G.M1 ${ }^{1}$, Dawood, M.I ${ }^{2}$, Kamar, M. S ${ }^{1}$, Saleh, S.M. ${ }^{1}$, Mahmoud, M. A ${ }^{1}$. \\ and El- Tohamy, A.M ${ }^{1}$ \\ ${ }^{1}$ Nuclear Materials Authority, P.O. Box 530, El-Maadi, Cairo, Egypt \\ ${ }^{2}$ Faculty of science, Minufiya University, Sheben El Kom, Egypt
}

\begin{abstract}
Two forms of pegmatite have been distinguished (segregations and dikes) hosted in the cataclastic rocks, at the Abu Rusheid area, southeastern Desert of Egypt. The cataclastic rocks covering an area about 2 $\mathrm{km}^{2}$, and composed of (from base to top); protomylonite, mylonite, ultramylonite, and quartzite with gradational contacts. The segregations are unzoned, flat lenses, less than $1 \mathrm{~m}$, while the dikes, usually of the zoned type, have (2-15 $\mathrm{m}$ in length, and $0.3 \mathrm{~m}$ in width), trending NNW-SSE and dipping 10-30\% WSW parallel to banding of the cataclastic rocks. Albitization, chloritization, fluoritization and silicification are the major alteration processes in the cataclastics and pegmatites due to the effect of hydrothermal solution.
\end{abstract}

The total REE content in the pegmatite ranges from 44 to 824 ppm with 342 ppm as the average. LREE is more enriched than the HREE in the pegmatite $(\Sigma L R E E / \Sigma H R E E=7.8)$ and related to the presence of allanite- $(\mathrm{Ce})$ and monazite- $(\mathrm{Ce})$. Hydrothermal alteration during post-magmatic stages is shed light on the development of $M$-type tetrad effect in the REE pattern.

The rare metals-bearing minerals such zircon, monazite - (Ce), allanite - (Ce), Nb-Ta minerals (columbite-( $\mathrm{Fe})$ and euxenite-(Y), base metals (pyrite and molybdite), beryl and radioactive minerals (thorite, uranophane, torbernite and kasolite) have been found in the pegmatites. Isoconcentration maps show abnormal contents of $\mathrm{Nb}, \mathrm{Zr}, \mathrm{Y}, \mathrm{Pb}, \mathrm{eU}$ and $\mathrm{eTh}$, and could be considered as low grade ores.

The Abu Rusheid pegmatites show low-CaO content (1 \% av.), high Fe/Mg ratio (5.9 av.), enrichment of HFSE $(\mathrm{Nb}, \mathrm{Zr}, \mathrm{Y}, \mathrm{U}, \mathrm{Th})$, peraluminous, A-type post-orogenic tectonic setting and their mineral composition supporting the NYF nature of the pegmatites.

Keywords: Abu Rusheid, Pegmatite, Rare Metals, REEs.

\section{INTRODUCTION}

Highly fractionated granitic pegmatites are sometimes zoned with respect to texture and mineral assemblages, and pegmatites are of great interest for their economic potential, being primary sources of $\mathrm{U}, \mathrm{Th}, \mathrm{Nb}, \mathrm{Ta}, \mathrm{Li}, \mathrm{Be}, \mathrm{Cs}$ and ceramic feldspar, however, the origin and petrogenesis of granitic pegmatites are still highly debated. Currently there are two genetic models to explain the origin of pegmatitic melts: (i) fractionation of igneous intrusions (Černý and Ercit 2005; Simmons and Webber 2008) and; (ii) direct anatexis of country rocks (Simmons and Webber 2008).

The mechanism(s) by which the magma enrichment in incompatible elements is of special interest because these residual magma may: (1) be inject into the surrounding rocks to crystallize as rare metal pegmatite, (2) to crystallize in-situ as granites containing primary rare metal minerals; and (3) to partition ore elements into magmatic hydrothermal fluids with precipitation during subsequent pervasive alteration, particularly in tin-bearing system (Cerny, 1991).

The study area is located $90 \mathrm{~km}$ south of Marsa Alam City on the Red Sea coast at the southern part of the Eastern Desert of Egypt (Fig.1). The present study aims to investigate the mineralogy and geochemistry of pegmatites at Abu Rusheid area compared with the host rocks (cataclastic rocks). Throw lights on a role of hydrothermal alterations in redistributions and the concentration of rare metals in the pegmatites. 


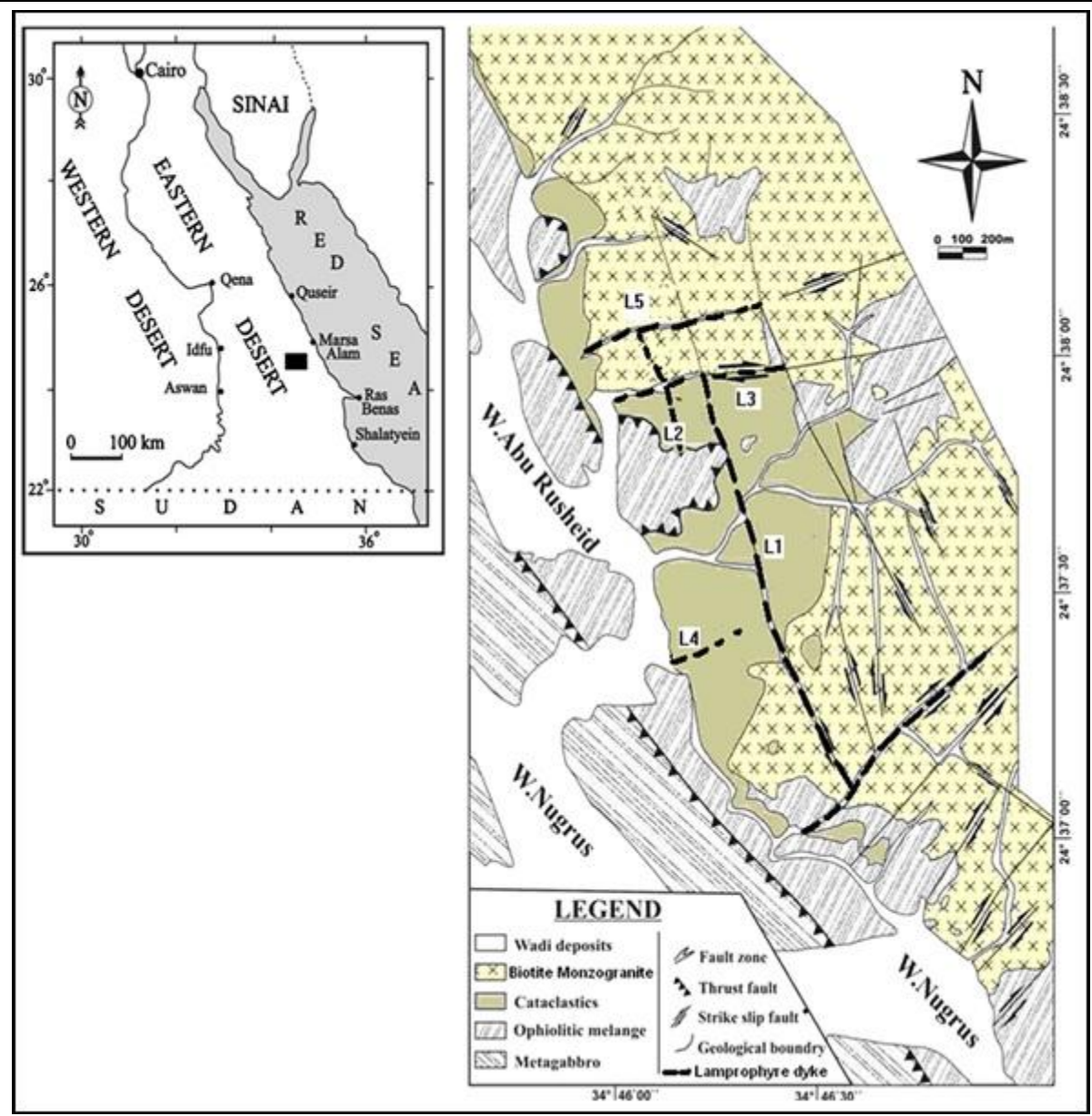

Fig.1. Geologic map of The Abu Rusheid area, South Eastern Desert, Egypt(after Ibrahim et al., 2010).

\section{Methodology}

Seventy (70) samples from pegmatites were analyzed as major oxides and trace elements and ten (10) samples were analyzed as REE. All chemical analyses have been carried out at Nuclear Materials Authority (NMA), Egypt. The X-ray fluorescence technique (XRF) was used to determine the trace element contents using PHILIPS X'Unique-II spectrometer as well as rare earth elements were measured by ICP-MS spectrometry. The studied rock samples were investigated radiometrically in the field using RS-230 BGO Super-Spec portable radiation detector. This detector is full assay capability with data in $\mathrm{K} \%$, eU (ppm), Ra (ppm) and eTh (ppm).

Five technological samples ( $5 \mathrm{~kg}$ for each one) were crushed, grinded and quartered. The samples were sieved and the size fraction -60 to +120 meshes was washed and separated by heavy liquid (bromoform). The heavy fractions were subjected to the magnetic fractionation using Frantz Isodynamic Magnetic Separator (Model LB 1). The intended minerals were picked under binocular microscope to obtain mono-mineral fraction for identification and analysis. The identification was carried out by the Environmental Scanning-Electron Microscope (ESEM model Philips XL30) supported by energy dispersive spectrometer (EDX) unit was used at $25-30 \mathrm{kV}$ accelerating voltage, 1-2 mm beam diameter and 60-120 second counting time, and X-ray diffraction techniques (XRD), using Philips PW 3710/31 diffractometer, scintillation counterr; Cu-target tube and Ni filter .

\section{Geologic Setting}

The tectono- stratigraphic sequence of the Precambrian rocks of the Abu Rusheid area (Fig. 1) arranged as follows: (a) ophiolitic metagabbro, (b) ophiolitic mélange, consisting of ultramafics and layered metagabbro set in metasediment matrix,(c) cataclastic rocks, (d) post-orogenic granites and (e) dykes and veins represented by lamprophyres, pegmatite and quartz veins (Saleh, 1998; Assaf et al. 2000; Ibrahim et al. 2004). These rocks are subjected to polycyclic deformation and metamorphism and characterized by regional WNW-ESE thrusting. Such thrusting is assigned to an age between 682 $\mathrm{Ma}$ (the time of emplacement of the older granitoids) and 565 to $600 \mathrm{Ma}$, the time of intrusion of the younger granites (Stern and Hedge, 1985). 
The ophiolitic metagabbros (Fig. 1) are layered, relatively highly foliated and thrusted over the ophiolitic mélange along WNW-ESE direction (Nugrus thrust fault) from the southwest and south with low to high angles $\left(30^{\circ}-60^{\circ}\right)$. The ophiolitic mélange represents the hanging wall of the major thrust in the study area. It comprises a metamorphosed sedimentary matrix (talc-schist, beryliferous tremolite/actinolite schists, sillimanite graphite schist and garnetiferous hornblende biotite schist, phologopite schist and garnetiferous staurolite schistc) enclosing allochthonous serpentinite, orthoamphibolite fragments mounted in schists. The ophiolitic mélange and ophiolitic metagabbro thrusted over the cataclastic rocks.

The cataclastic rocks (Fig.1) contain blocks of mafic-ultramafic rocks and bands of tremoliteactinolite $(1 \times 15 \mathrm{~m})$. These rocks are light grey to grey in color, fine to coarse-grained and exhibit layering between protomylonite and mylonites and characterized by absence of enclaves. The altered rock acquires reddish to yellowish colour due to staining with iron solutions. Some pyrite crystals were removed leaving vugs filled with quartz, iron oxides, carbonates and $\mathrm{U}-$ minerals.

The cataclastic rocks, covering an area of about $2 \mathrm{~km}^{2}$, are represented by protomylonite, mylonite, ultramylonite, and quartzite with gradational contacts), highly sheared, banded (N-S) and cut by two approximately perpendicular shear zones (NNW-SSE and E-W trends) differ in length, age and mineralization. The shear zones range from 2 to $10 \mathrm{~m}$ in width and $400-1500 \mathrm{~m}$ in length with vertical dip and extruded by lamprophyre dikes. The later is a good physical and chemical trap for U, REEs, $\mathrm{Cu}, \mathrm{Zn}, \mathrm{Ag}, \mathrm{Pb}$ and $\mathrm{Y}$ (Ibrahim et al.2015). The cataclastic rocks have been considered as a passamitic gneisses of sedimentary origin (Hassan, 1964; Saleh, 1998; Assaf et al. 2000), whereas, Ibrahim et al. $(2004,2006,2007,2010,2015)$ described these rocks as cataclastic rocks. Khour Abalea $(1.5 \mathrm{Km}$ in length, 10-20 $\mathrm{m}$ in width) located at the middle part of the cataclastic rocks (Fig. 2). It was formed as a result of deep strike-slip faults, forming shear zones in ENE-WSW, NNW-SSE, N-S and NNE-SW trends respectively, with common pegmatites (segregations and dikes) and quartz veins.

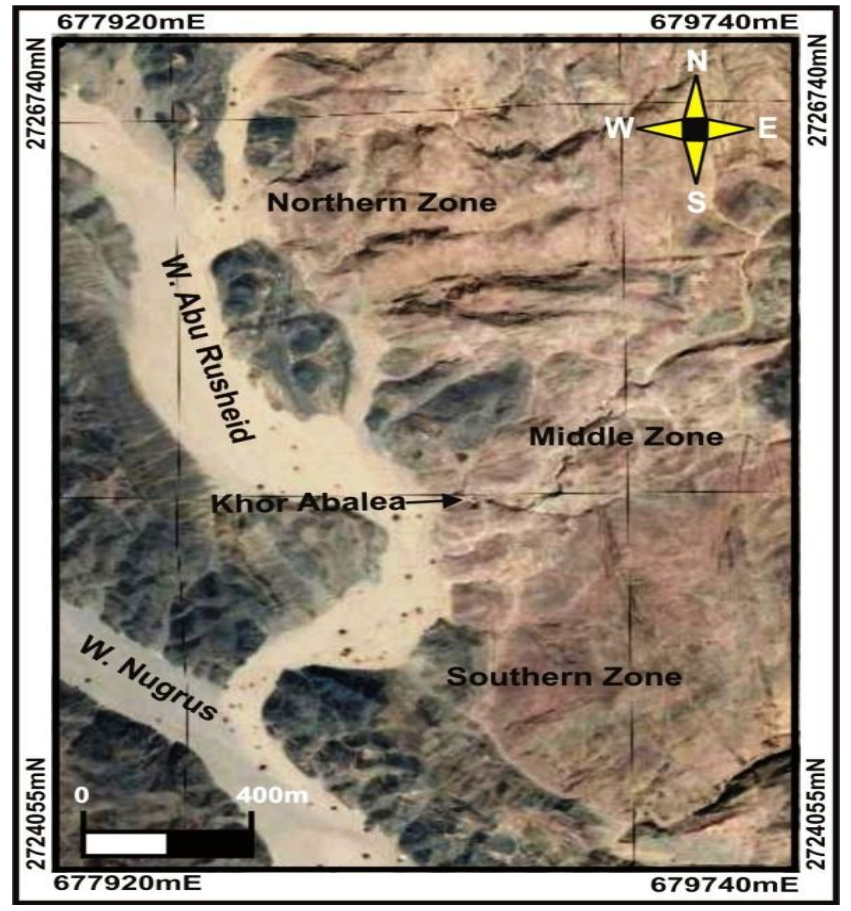

Fig.2. Google Earth image of the Abu Rusheid area showing the location of Khour Abalea zone and northern and southern zones, Abu Rusheid area.

The geology, geochemistry and mineralogy of the cataclastic rocks and associated lamprophyre dykes at Abu Rusheid area were studied by Ibrahim et al. (2006, 2007, 2010 and 2015).

Abu Rusheid granitic pluton is an elongated body extending NW-SE for about $12 \mathrm{~km}$ with width about $3 \mathrm{~km}$ (outside the mapped area). The Late- to Post-orogenic granitic rocks occupy the major part of the mapped area intruded the cataclastic rocks with sharp contacts.

They are represented from the NW direction by porphyritic biotite monzogranites followed by two mica peraluminous granites, and muscovite granites occupy the SE part of the pluton (Ibrahim et al. 2004). 
Two morphological types of pegmatites have been distinguished (segregations and dikes) intruded in the cataclastic rocks. The segregations are formed by segregation of the host rocks (Fig. 3), so they have not sharp contacts with the host rocks, compared with the dikes (Figs. 3c - d). The pegmatite segregations are flat lenses (less than $1 \mathrm{~m}$ ), distributed heterogeneous in the cataclastic rocks. The pegmatite dikes intruded in the cataclastic rocks (protomylonite, mylonite, ultramylonite), except quartzite. These dikes trending in NNW-SSE and dip $10^{\circ}-30^{\circ} / \mathrm{WSW}$ and are emplaced parallel to cataclastic bands. Albitization, chloritization and fluoritization were major hydrothermal alteration processes. The pegmatite dikes $(2-15 \mathrm{~m}$ in length and $0.3 \mathrm{~m}$ in width) are usually of the zoned type. The zonation starts with quartz at the core (smoky to milky in color) associated with micas (muscovite or $\mathrm{Li}$-mica) followed by feldspars at the margins. The feldspars vary in colors from pink to milky and in composition from K-feldspar to Na-feldspar. Sometimes intercalations of both types are common due to albitization of k-feldspars. Some pyrite crystals were removed leaving vugs. These vugs are common in quartz and decrease in feldspars and could be considered as physical traps for mineralization.

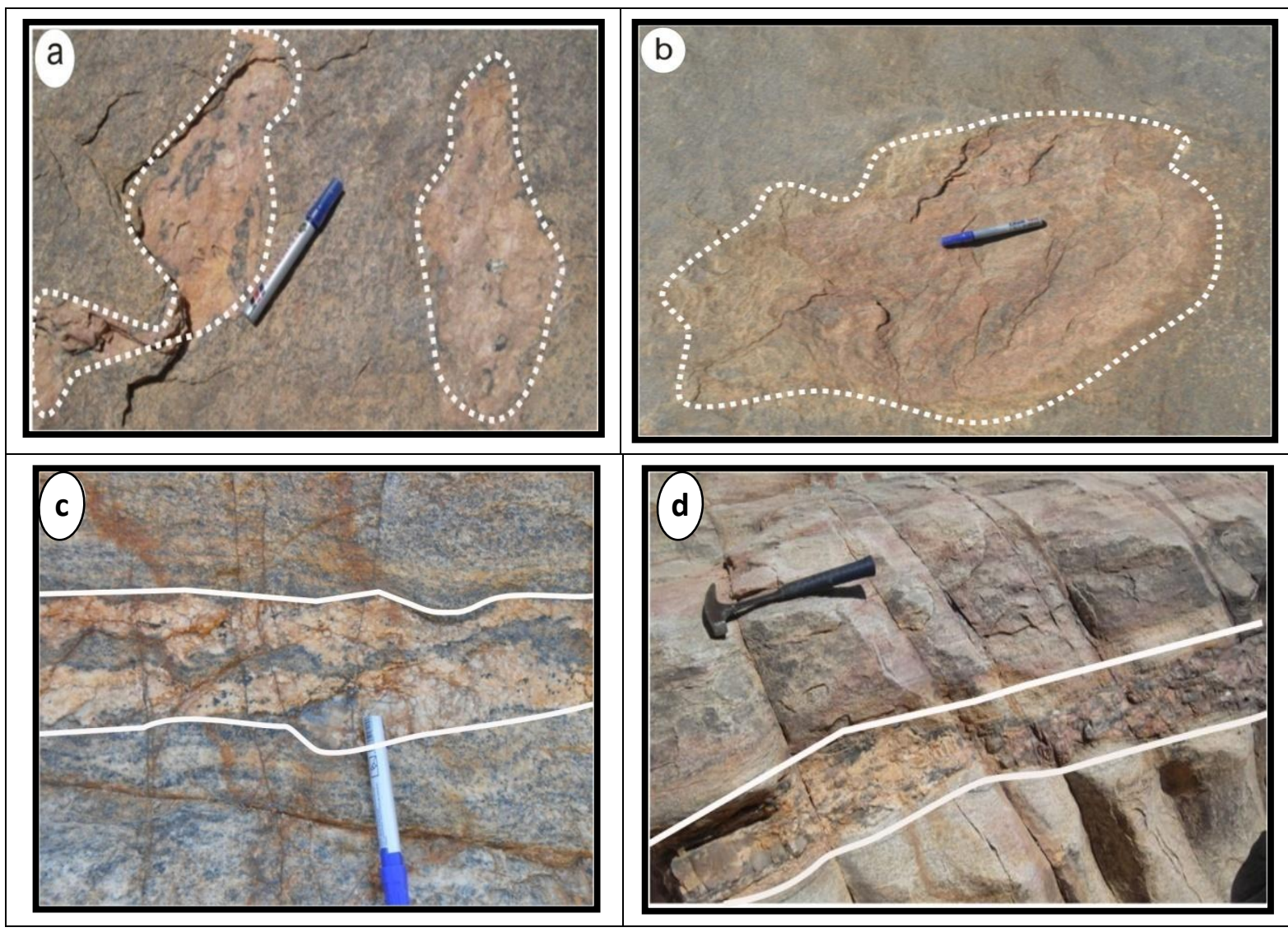

Fig.3. Photomicrographs showing $a-b)$ pegmatite segregations andc-d)dikes parallelto banding planes of the cataclastic rocks. Abu Rusheid area, Looking NW.

The pegmatites are composed of euhedral to subhedral alkali feldspars, sodic plagioclase, quartz, muscovite and biotite. Garnet (spessartine), allanite-(Ce), zircon, apatite, fluorite, beryl, ilmenite and monazite-(Ce) are the common accessories. Perthite is probably developed due to the action of $\mathrm{Na}-$ bearing solutions penetrating through the cleavage planes in the K-feldspar resulting the replacement of the K-feldspar by sodium and the precipitation of albite. Myrmekite texture is common. Plagioclase $\left(\mathbf{A n}_{6-18}\right)$ presents as sub-to euhedral crystals that are often corroded and infiltrated by quartz. Garnet occurs as pale pink small equi-dimensional crystals free from quartz inclusions. It obvious high relief, isotropic, irregular and rounded shape. Sometimes, faint layering of muscovite and garnet are locally encountered. It is argued that the increase in the hydroxyl and fugitive constituents as well as, silica and alkali as well as the relative decrease in ferromagnesian ( $\mathrm{Fe}$ and $\mathrm{Mg}$ ) would discourage the development of biotite, but localized changes in fluid chemistry resulting in locally more peraluminous environments enabling crystallization of peraluminous minerals (garnet and muscovite). Allanite-(Ce) occurs as minute anhedral crystals sporadically scattered in the rock but often associated with biotite and garnet. 


\section{Mineralogy}

The mineralogical study on pegmatites reveal the presence of 1) radioactive minerals represented by metatorbernite, uranophane, B-uranophane, kasolite and thorite, 2) $\mathrm{Nb}$-Ta minerals include ; columbite-(Fe) and euxenite-(Y), 3) base metals (pyrite and molybdite), and 4) rare metal-bearing minerals (zircon, monazite $-(\mathrm{Ce})$, allanite- $(\mathrm{Ce})$, xenotime $-(\mathrm{Y})$, and beryl) as shown in Table (1) compared with the main mineralogy of the cataclastic rocks reported by Ibrahim et al. (2004).

Table1. Summary of the recorded minerals in the cataclastic rocks after Ibrahim et al., (2004) and in the present pegmatite rocks, Abu Rusheid area.

\begin{tabular}{|c|c|c|}
\hline Minerals & Cataclastic rocks & $\begin{array}{l}\text { Mineralized pegmatite } \\
\text { present study }\end{array}$ \\
\hline U- minerals & $\begin{array}{c}\text { Kasolite }[\mathrm{Pb}(\mathrm{UO} 2) \mathrm{SiO} 3 .(\mathrm{OH}) 2], \\
\text { Curite }[3 \mathrm{PbO} .8 \mathrm{UO} 3.4 \mathrm{H} 2 \mathrm{O}], \\
\text { Boltwoodite } \\
{[\mathrm{K} 2(\mathrm{UO} 2) 2(\mathrm{SiO} 3 \mathrm{OH}) 2.5 \mathrm{H} 2 \mathrm{O}],} \\
\text { Autunite }[\mathrm{Ca}(\mathrm{UO} 2) 2(\mathrm{PO} 4) 2.8 \mathrm{H} 2 \mathrm{O})], \\
\text { Coeffinite }[\mathrm{U}(\mathrm{SiO} 4)(\mathrm{OH})], \\
\text { Carnotite }[\mathrm{K} 2(\mathrm{UO} 2)(\mathrm{VO} 4) 2.3 \mathrm{H} 2 \mathrm{O}], \\
\text { Uranophane and } \beta-\text { uranophane } \\
\text { [CaO.2(UO3).2(SiO2).6(H2O)] } \\
\text { Torbernite }[\mathrm{Cu}(\mathrm{UO} 2) 2(\mathrm{PO} 4) 2.8- \\
12(\mathrm{H} 2 \mathrm{O})]\end{array}$ & $\begin{array}{c}\text { Torbernite }\left[\mathrm{Cu}\left(\mathrm{UO}_{2}\right) 2\left(\mathrm{PO}_{4}\right) 2.8-12\left(\mathrm{H}_{2} \mathrm{O}\right)\right] \\
\text { Uranophane and } \beta-\text { uranophane } \\
{\left[\mathrm{CaO} \cdot 2\left(\mathrm{UO}_{3}\right) \cdot 2\left(\mathrm{SiO}_{2}\right) \cdot 6\left(\mathrm{H}_{2} \mathrm{O}\right)\right]} \\
\text { Kasolite }\left[\mathrm{Pb}\left(\mathrm{UO}_{2}\right) \mathrm{SiO}_{3} \cdot(\mathrm{OH})_{2}\right]\end{array}$ \\
\hline Th- minerals & $\begin{array}{c}\text { Uranothorite }[(\mathrm{Th}, \mathrm{U}, \mathrm{Ce}) \mathrm{SiO} 4], \\
\text { Thorite [ThSiO4], } \\
\text { Cheralite [(Th,Ca,LREEs,U)(P,Si)O4] } \\
\text { and Thorianite }\end{array}$ & Thorite $\left[\mathrm{ThSiO}_{4}\right]$, uranothorite \\
\hline $\begin{array}{l}\text { Niobium - } \\
\text { Tantalum } \\
\text { Minerals } \\
\end{array}$ & $\begin{array}{c}\text { Ishikawaite[(U,Fe,Y)(Nb,Ta)2O6], } \\
\text { Columbite- Tantalate, Tapiolite }\end{array}$ & 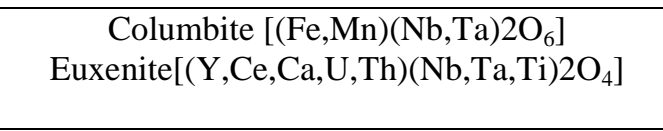 \\
\hline Base metals & $\begin{array}{c}\text { Arsenopyrite, Pyrite, Chacopyrite, } \\
\text { Bunsenite, Ilsemanite, Galena and } \\
\text { Nimite }\end{array}$ & Pyrite and Molybdite \\
\hline $\begin{array}{c}\text { Iron oxide } \\
\text { minerals }\end{array}$ & $\begin{array}{c}\text { Hematite, Goethite, Ilmenite, Jarosite, } \\
\text { Thuringite and Magnetite }\end{array}$ & Magnetite, Hematite and Ilmenite \\
\hline $\begin{array}{c}\text { Associated } \\
\text { minerals }\end{array}$ & $\begin{array}{l}\text { Zircon, Monazite, Fluorite, Allanite, } \\
\text { Xenotime and REE-silicate }\end{array}$ & $\begin{array}{l}\text { Zircon, Monazite-(Ce), Fluorite, Allanite-(Ce), } \\
\text { Xenotime-(Y), Beryl }\end{array}$ \\
\hline
\end{tabular}

\section{1-Radioactive minerals:}

1. A. Uranium minerals: Metatorbernite; is a uranium phosphate mineral, and is formed by the dehydration of torbernite and contains $75 \% \mathrm{U}, 11 \% \mathrm{Cu}$ with a minor amount of $\mathrm{Al}, \mathrm{Fe}, \mathrm{Ni}$ and $\mathrm{P}$ as confirmed by SEM (Fig.4a). Uranophane is usually associated with its dimorph, namely, betauranophane and composed of $86.7 \% \mathrm{U}, 5.3 \% \mathrm{Ca}, 3.3 \% \mathrm{Si}, 3.3 \% \mathrm{Fe}$ and $1.4 \% \mathrm{Al}(\mathrm{Fig} .4 \mathrm{~b})$. Kasolite constitutes of $60.22 \% \mathrm{U}, 25.4 \% \mathrm{~Pb}, 5.8 \% \mathrm{Si}, 2.3 \% \mathrm{Al}, 3.4 \% \mathrm{~K}$ and $2.88 \% \mathrm{Fe}$ (Fig.4c).

1. B. Thorite: Thorite is associated with fluorite, pyrite, zircon and iron oxides. Thorite mostly occurs at high-temperature hydrothermal formation. Thorite composed of $62.5 \% \mathrm{Th}, 5.4 \% \mathrm{U}, 15.6 \% \mathrm{Si}$, $10.3 \% \mathrm{Fe}$ and $6.2 \% \mathrm{Al}$ with low U/ Th (11.6 ) (Fig.4d).The ESEM analyses of uranothorite in the pegmatite include, $52.9 \% \mathrm{Th}, 13.7 \% \mathrm{U}, 11.5 \% \mathrm{Si}, 8.7 \%$ Fewith low U/Th (0.26) (Fig.4e).

\section{2-Nb- Ta minerals}

2.A.Columbite- $(\mathbf{F e})$ : The ESEM analyses for columbite indicate a predominance of columbite $(\mathrm{Nb}$ $>\mathrm{Ta}$ ), in association with $\mathrm{UO}_{2}, \mathrm{ThO}_{2}, \mathrm{CaO}$ and $\mathrm{TiO}_{2}$. The ESEM analyses show its typical composition of ferocolumbite (Fig.4f) and composed of $57 \% \mathrm{Nb}, 20 \% \mathrm{Fe}, 6 \% \mathrm{Ta}, 5.2 \% \mathrm{Ti}$ and $10.3 \% \mathrm{Si}$ with $\mathrm{Nb} / \mathrm{Ta}$ ratio $=9.6$.

2.B.Euxenite- (Y):Occurs as an orthorhombic prismatic crystals; typically metamict mineral. It is characterized by brittle, brilliant submetallic, waxy to resinous luster. The obtained chemical analysis $27.86 \% \mathrm{Nb}, 4.85 \% \mathrm{Ta}, 13.17 \% \mathrm{U}, 3.99 \% \mathrm{Th}, 17.99 \% \mathrm{Y}, 19.26 \% \mathrm{Ti}, 3.06 \% \mathrm{Ca}$ and $7.13 \% \mathrm{Fe}$ were confirmed by ESEM techniques (Fig.4g). 


\section{3- Base metals}

3.A.Pyrite: Occurs as large subhedral to anhedral grains with different sizes and shapes, characterized by its pale brass yellow color and ESEM analyses show $50.88 \% \mathrm{Fe}$ and $40.82 \% \mathrm{~S}$ (Fig.4h).

3.B. Molybdite: The ESEM analyses of molybdite show its typical composition, where Mo up to 93.3\% with $3.4 \%$ Caand $3.3 \%$ Si(Fig.4i).

\section{4-Rare metals}

4.A. Zircon: Two types of zircon at Abu Rusheid pegmatite have been recorded; the first one is unaltered zircon, where the second type is altered zircon (Fig.4j ). In spite of the fact that zircon is a good host of the HREE, they have not been detected in unaltered one of the analyzed zircon due to their mobilization during alteration. The EDX analysis of unaltered one indicates marked enrichment $\mathrm{Zr}$ where $\mathrm{Zr} / \mathrm{Hf}$ ratio (33.5) always below the chondritic limit (35), suggesting relative enrichment of the heavier isovalent (Hf) due to metasomatism and its alteration products. While the second one have total REEs equal to $50 \%$ and $\mathrm{Zr} / \mathrm{Hf}$ ratio (14.7). Wang et al. (2000) reported that the $\mathrm{Hf}$ enrichment in zircon, and the association of exotic REE and HFSE bearing minerals are linked to hydrothermal activity, suggesting that during the last stage of crystallization of the A-type magma, fluids enriched in REE, HFSE, $\mathrm{F}, \mathrm{CO}^{2-}$ and $\mathrm{PO}_{4}^{3-}$ were released.

The majority of scanned spot is composed of $\mathrm{ThO}_{2}$ content more common than $\mathrm{UO}_{2}$ content and have $\mathrm{ThO}_{2} / \mathrm{UO}_{2}$ ratio equal to 1.9 .

4.B. Allanite-(Ce):Occurs as irregular grains and crystals in reddish feldspars associated with zircon. It is brown, pitch-black occasionally yellow in color. Allanite $-(\mathrm{Ce})$ have formed from a volatileenriched magma. Allanite-(Ce) common in some NYF-type pegmatite (Williams, 2002) and is confirmed by ESEM containing $33.57 \% \mathrm{Ce}, 16.26 \% \mathrm{La}, 12.41 \% \mathrm{Nd}, 11.87 \% \mathrm{Th}, 3.71 \% \mathrm{Pr}, 3.04 \% \mathrm{U}$ and $2.39 \%$ Y (Fig.4k).

4.C. Monazite-(Ce):Usuallyassociated with xenotime-(Y), columbite-(Fe) and zircon. Monazite-(Y) prefers NYF-type, but may occur in small quantities in LCT-type pegmatites (Williams, 2002). The ESEM analyses of monazite - (Ce) composed of $33.5 \% \mathrm{P}, 10.6 \% \mathrm{Th}, 48.8 \%$ LREEsand $1.3 \%$ U(Fig.41).

4.D. Xenotime-(Y):Occurs associated with fluorite and hematite and its ESEM analyses show $49 \% \mathrm{Y}$, 26.8\% P,12.95\% HREEswith rare $\mathrm{Si}$ and $\mathrm{Al}$ (Fig.4m).

4.E. Fluorite crystals have variable colors as colorless, blue, and deep violet. The ESEM analyses show $15.8 \%$ F,2\% Yand $82.19 \%$ Ca (Fig.4n).

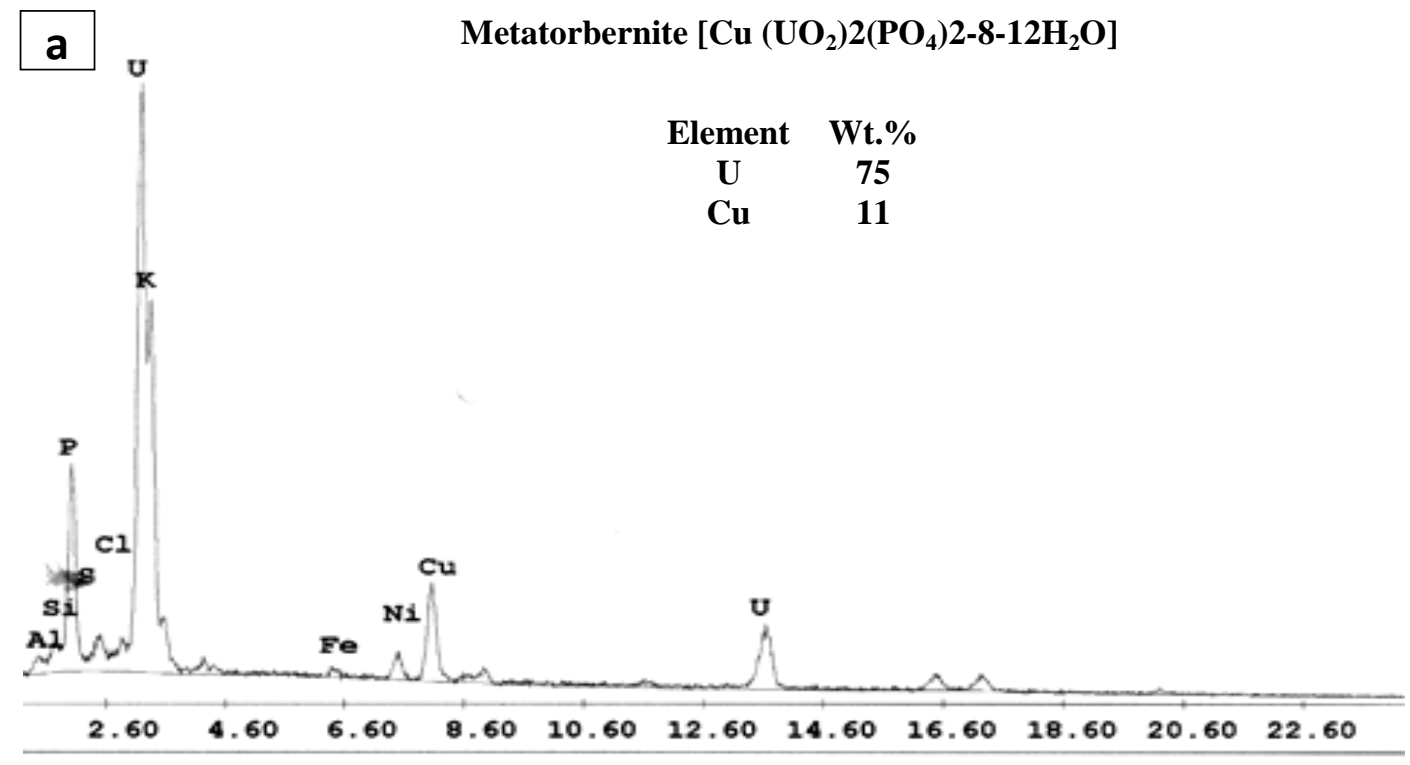


Rare Metals Mineralization in Pegmatite at Abu Rusheid Area, South Eastern Desert, Egypt
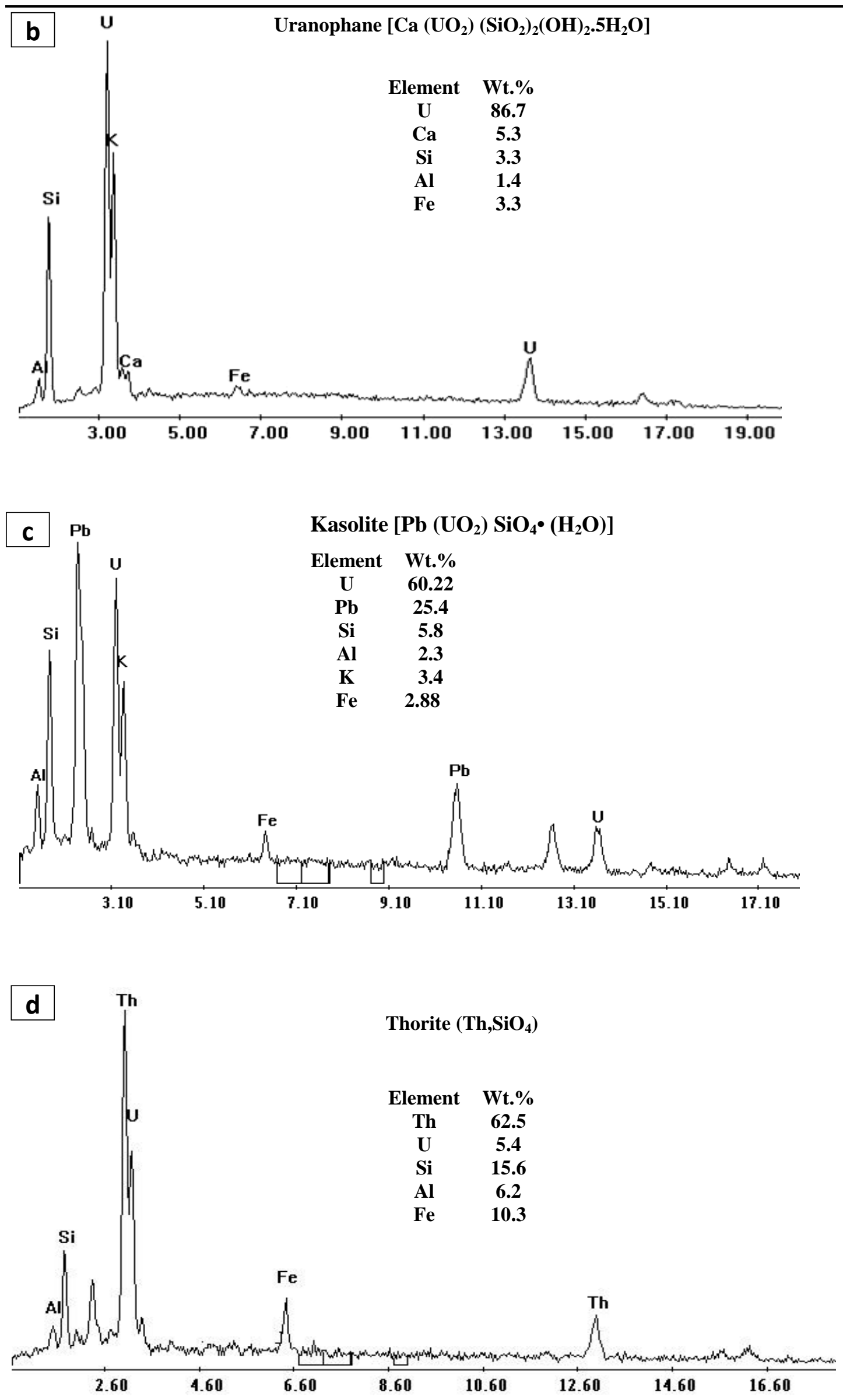
Ibrahim, M.E et al.
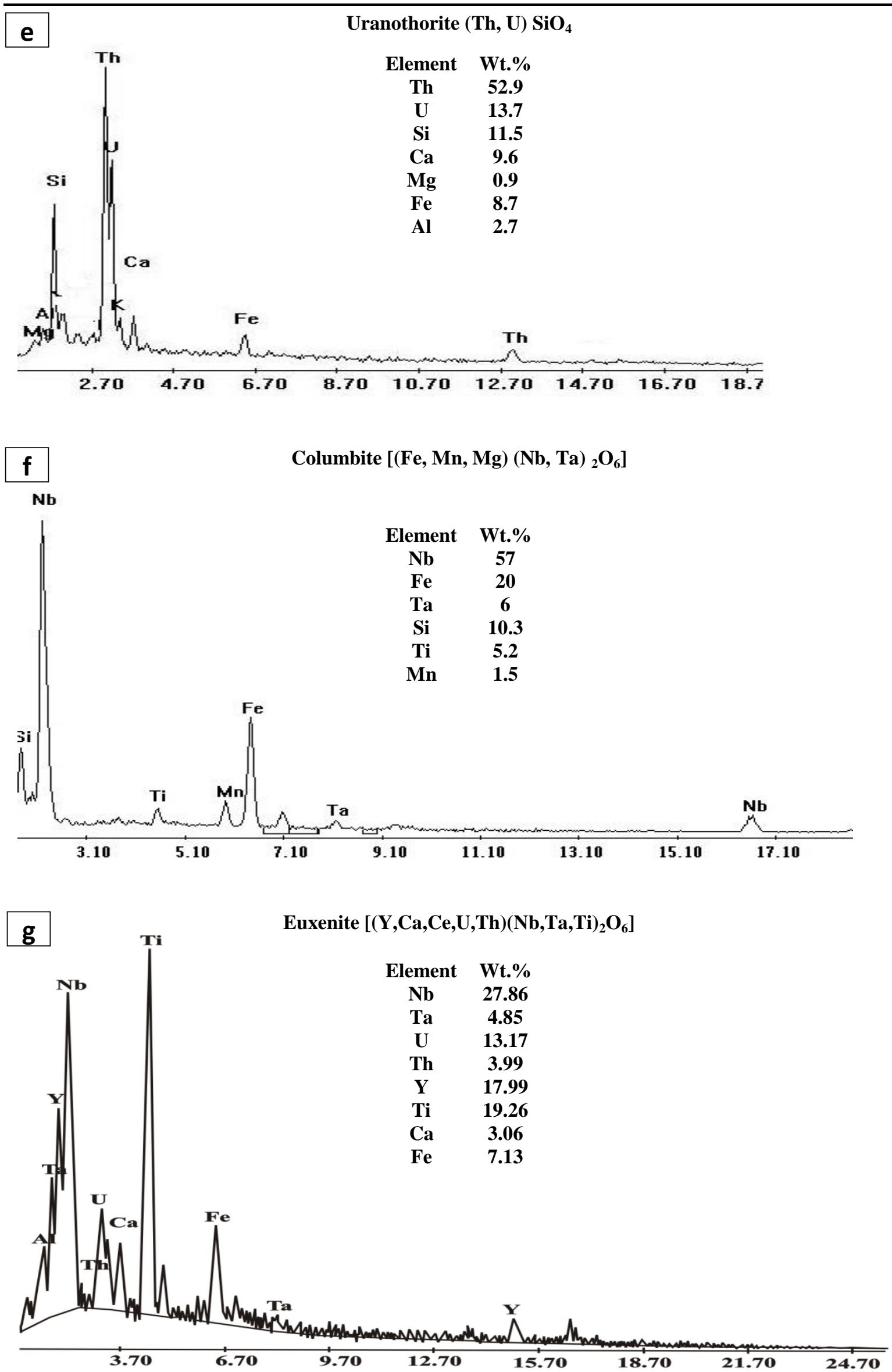
Rare Metals Mineralization in Pegmatite at Abu Rusheid Area, South Eastern Desert, Egypt
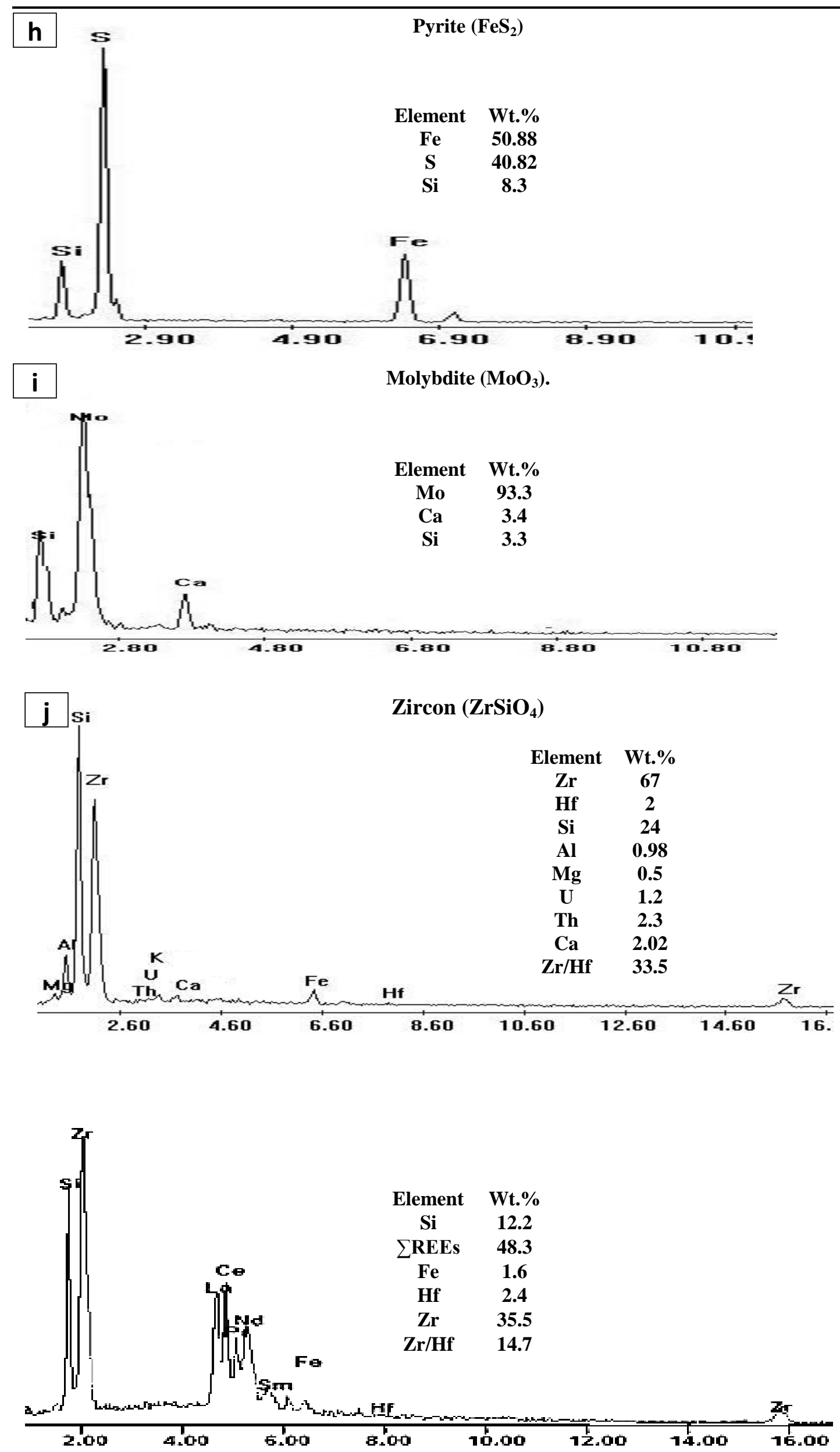
Ibrahim, M.E et al.



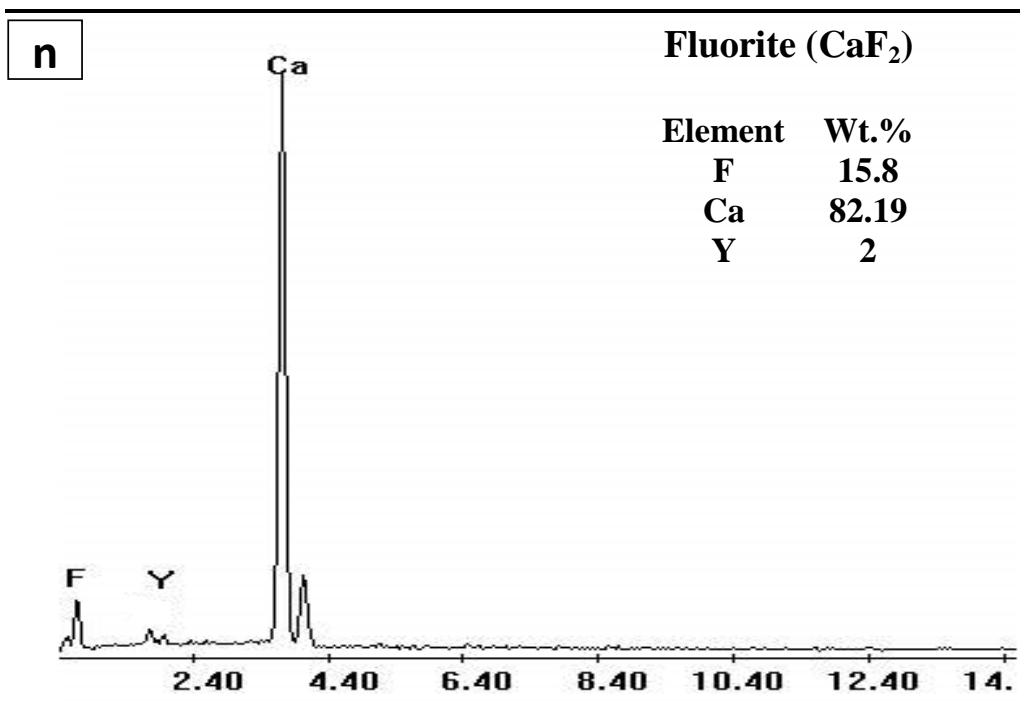

Figs.4. EDEX of the recorded minerals, Abu Rusheid uraniferous pegmatites, SED, Egypt

\section{GEOCHEMISTRY}

\subsection{Major Elements}

Abu Rusheid cataclastic rocks subdivided into three sub-zones based on Khour Abalea as base line into; a) northern Abalea zone, b) khour Abalea (middle) zone and c) southern Abalea zone (Fig. 2). Pegmatites have moderate to high silica ( $74.5 \%$ av.), $\mathrm{Al}_{2} \mathrm{O}_{3},\left(13.04 \%\right.$ av.), normal $\mathrm{TiO}_{2}(0.11 \%$ av.), $\mathrm{MnO}\left(0.03 \%\right.$ av.), $\mathrm{MgO}\left(0.24 \%\right.$ av.), $\mathrm{Na}_{2} \mathrm{O}$ (4.4\% av.) and $\mathrm{K}_{2} \mathrm{O}(4.2 \%$ av.) contents, low-CaO content (1\% av.) and high $\mathrm{Fe} / \mathrm{Mg}$ ratio (5.9 av.) (Fig.5). Average value of $\mathrm{Na}_{2} \mathrm{O} / \mathrm{K}_{2} \mathrm{O}$ and mol $\mathrm{A} / \mathrm{CNK}$ ratio are generally $>1 \%$.

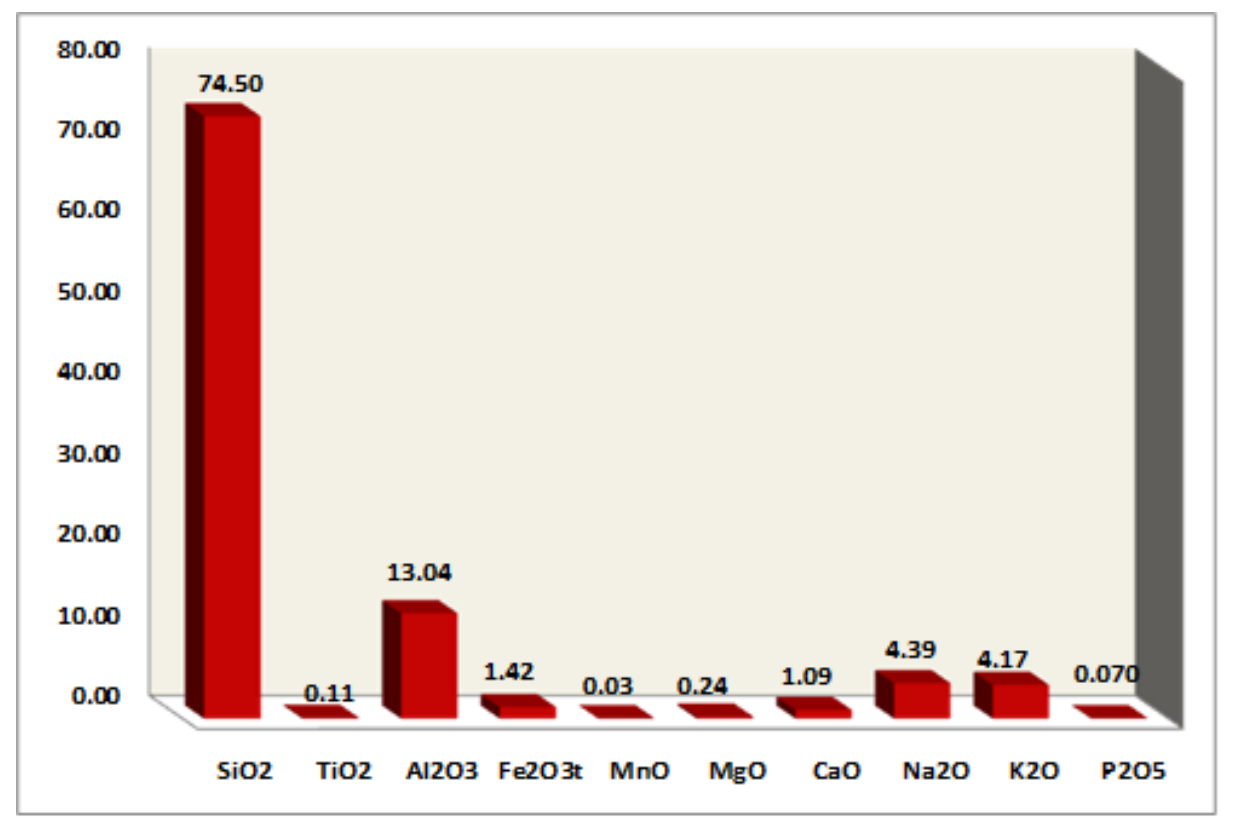

Fig.5. Bar diagram showing the average contents of major oxides (Wt. \%) in pegmatites, Abu Rusheid area.

\subsection{Trace Elements}

Trace element data with some critical element ratios a usually employed for inferring regional characteristic, nature of source rocks (Whalen et al. 1987) and tectonic setup (Pearce et al. 1984; Brown et al. 1984). In general, the pegmatites from northern to southern zone, shows moderate to high abundance of $\operatorname{Sr}(19-181 \mathrm{ppm}$, av. $96 \mathrm{ppm}), \mathrm{Ba}$ (23-405 ppm, av. $90 \mathrm{ppm})$, high Rb (116-3084 ppm, av.1427 ppm), high Nb (78-1179 ppm, av.382 ppm) and high Y(116-1932 ppm, av.891 ppm) (Table 2). The critical element ratio is significant in characterization of pegmatites and interpretation of petrogenetic history. 
The pegmatites show low $\mathrm{K} / \mathrm{Rb}$ (0.0024), $\mathrm{Ba} / \mathrm{Rb}(0.05-0.11)$ and high $\mathrm{Rb} / \mathrm{Sr}$ (11.4-18.3), which are essential criteria for uranium exploration in differentiated granite (Viswanathan, 1993). In general, ratio of $\mathrm{Ba} / \mathrm{Sr}$ increases with fractionation, which indicates enrichment of $\mathrm{Ba}$ over Sr. But in studied rocks, $\mathrm{Sr}$ depletion, may be accompanied by drop in $\mathrm{Ba}$ where $\mathrm{Ba} / \mathrm{Sr}$ varies from (0.74-1.2 )in pegmatites. The enrichment of uranium in pegmatites $(57-455 \mathrm{ppm})$ and cataclastics $(50-975 \mathrm{ppm})$ are related to secondary U- minerals (uranophane, B-uranophane, torbernite and kasolite) (Table 2).

Table2. Average of trace elements (in ppm) of pegmatite at the northern, middle and southern Khour Abalea zone respectively, compared with cataclastics of the Abu Rusheid area

\begin{tabular}{|c|c|c|c|c|}
\hline $\begin{array}{c}\text { Trace } \\
\text { element }(\mathbf{p p m})\end{array}$ & $\begin{array}{l}\text { Northern Abalea Zone } \\
\qquad(\mathrm{n}=11)\end{array}$ & $\begin{array}{l}\text { Middle Abalea Zone } \\
\qquad(\mathrm{n}=\mathbf{4 4})\end{array}$ & $\begin{array}{l}\text { Southern Abalea Zone } \\
\qquad(\mathrm{n}=15)\end{array}$ & $\begin{array}{c}\text { Cataclastics } \\
\text { Host Rock } \\
\text { N=5 }\end{array}$ \\
\hline $\mathrm{Cr}$ & $\begin{array}{c}34 \\
(10-34) \\
\end{array}$ & $\begin{array}{c}41 \\
(21-61) \\
\end{array}$ & $\begin{array}{c}40 \\
(16-95)\end{array}$ & $15-80$ \\
\hline $\mathbf{N i}$ & $\begin{array}{c}10 \\
(2-17) \\
\end{array}$ & $\begin{array}{c}18 \\
(7-41) \\
\end{array}$ & $\begin{array}{c}12 \\
(5-25) \\
\end{array}$ & $20-38$ \\
\hline $\mathbf{C u}$ & $\begin{array}{c}126 \\
(25-319) \\
\end{array}$ & $\begin{array}{c}66 \\
(9-289) \\
\end{array}$ & $\begin{array}{c}143 \\
(25-501) \\
\end{array}$ & $15-333$ \\
\hline $\mathbf{Z n}$ & $\begin{array}{c}224 \\
(76-401) \\
\end{array}$ & $\begin{array}{c}434 \\
(122-1515) \\
\end{array}$ & $\begin{array}{c}1026 \\
(308-3549) \\
\end{array}$ & $662-2750$ \\
\hline $\mathbf{Z r}$ & $\begin{array}{c}969 \\
(260-2214) \\
\end{array}$ & $\begin{array}{c}1331 \\
(207-4316)\end{array}$ & $\begin{array}{c}1738 \\
(442-3384)\end{array}$ & $1611-3037$ \\
\hline $\mathbf{R b}$ & $\begin{array}{c}1906 \\
(1031-3084) \\
\end{array}$ & $\begin{array}{c}1347 \\
(300-2993) \\
\end{array}$ & $\begin{array}{c}1029 \\
(116-1717) \\
\end{array}$ & $884-1345$ \\
\hline $\mathbf{Y}$ & $\begin{array}{c}626 \\
(179-1289) \\
\end{array}$ & $\begin{array}{c}852 \\
(116-1932) \\
\end{array}$ & $\begin{array}{c}1196 \\
(480-1863) \\
\end{array}$ & $226-1200$ \\
\hline $\mathbf{B a}$ & $\begin{array}{c}91 \\
(30-405) \\
\end{array}$ & $\begin{array}{c}70 \\
(23-245) \\
\end{array}$ & $\begin{array}{c}109 \\
(25-302) \\
\end{array}$ & $144-234$ \\
\hline $\mathbf{P b}$ & $\begin{array}{c}673 \\
(194-1091) \\
\end{array}$ & $\begin{array}{c}514 \\
(40-2592) \\
\end{array}$ & $\begin{array}{c}754 \\
(246-1591) \\
\end{array}$ & $600-1915$ \\
\hline $\mathrm{Sr}$ & $\begin{array}{c}104 \\
(19-134) \\
\end{array}$ & $\begin{array}{c}94 \\
(21-217) \\
\end{array}$ & $\begin{array}{c}90 \\
(22-181) \\
\end{array}$ & $25-200$ \\
\hline $\mathbf{N b}$ & $\begin{array}{c}264 \\
(84-1179) \\
\end{array}$ & $\begin{array}{c}443 \\
(78-990) \\
\end{array}$ & $\begin{array}{c}439 \\
(91-767) \\
\end{array}$ & $400-1300$ \\
\hline $\mathrm{eU}$ & $\begin{array}{c}87 \\
(57-134)\end{array}$ & $\begin{array}{c}129 \\
(58-249)\end{array}$ & $\begin{array}{c}275 \\
(76-455)\end{array}$ & $50-975$ \\
\hline eTh & $\begin{array}{c}228 \\
(134-495) \\
\end{array}$ & $\begin{array}{c}310 \\
(101-1939)\end{array}$ & $\begin{array}{c}426 \\
(132-633) \\
\end{array}$ & $126-2200$ \\
\hline
\end{tabular}

$\mathrm{n}=$ number of the samples

Isoconcentration maps (Fig.6) were constructed for some trace elements ( $\mathrm{Nb}, \mathrm{Zr}, \mathrm{Y}$ and $\mathrm{Pb}$ ) showing their surface distribution in pegmatites. $\mathrm{Nb}$ - content (ranges from 50 to $>650 \mathrm{ppm}$, on average 400 $\mathrm{ppm})$ and attributed to the presence of columbite- $(\mathrm{Fe})$ and euxenite- $(\mathrm{Y})$ minerals. Zr- content (varies from 200 to $>2000 \mathrm{ppm}$, on average 1000ppm), Y- content (ranges from 100 to $>1300 \mathrm{ppm}$, on average 500ppm) and related to xenotime- $(\mathrm{Y})$. Pb- contents (vary from 40 to $900 \mathrm{ppm}$, on average $600 \mathrm{ppm})$. The average contents of rare metals in the host rocks $(\mathrm{Zr}=2000 \mathrm{ppm}, \mathrm{Y}=500 \mathrm{ppm}$, $\mathrm{Nb}=500 \mathrm{ppm}$ and $\mathrm{Pb}=200 \mathrm{ppm}$, Ibrahim et al. 2010) are relatively comparable with the intruded pegmatites.

The distribution of trace elements (Fig.6a-d) revealed that, Khour Abalea and its southern zone are richer in $\mathrm{Zr}, \mathrm{Zn}, \mathrm{Y}, \mathrm{Pb}$ and $\mathrm{Nb}$ elements (Table 2) than the northern zone. This related to the pathways (NNE, NE and ENE trends) and the common occurrence of zircon, xenotime-(Y), galena and columbite-(Fe). Whereas the northern part of Abalea is more enriched in $\mathrm{Rb}$ (1906 ppm) than the other two zones (1347 and $1028 \mathrm{ppm}$ respectively) due to the presence of amazonite veinlets (Table 2).

In light of the Abu Rusheid pegmatites, the following observations can be pointed out: 1-Geochemical maps based on 70 pegmatite samples were used to delineate the most suitable locations for the surface and probable hidden mineralization (Figs. 4). 2- The area have background $U$ and Th values higher than the corresponding Clark value, it was also observed that, $\mathrm{Nb} \mathrm{Pb}, \mathrm{Y}$ and $\mathrm{Zr}$ have abnormal contents and could be considered as low grade ores. 
Rare Metals Mineralization in Pegmatite at Abu Rusheid Area, South Eastern Desert, Egypt
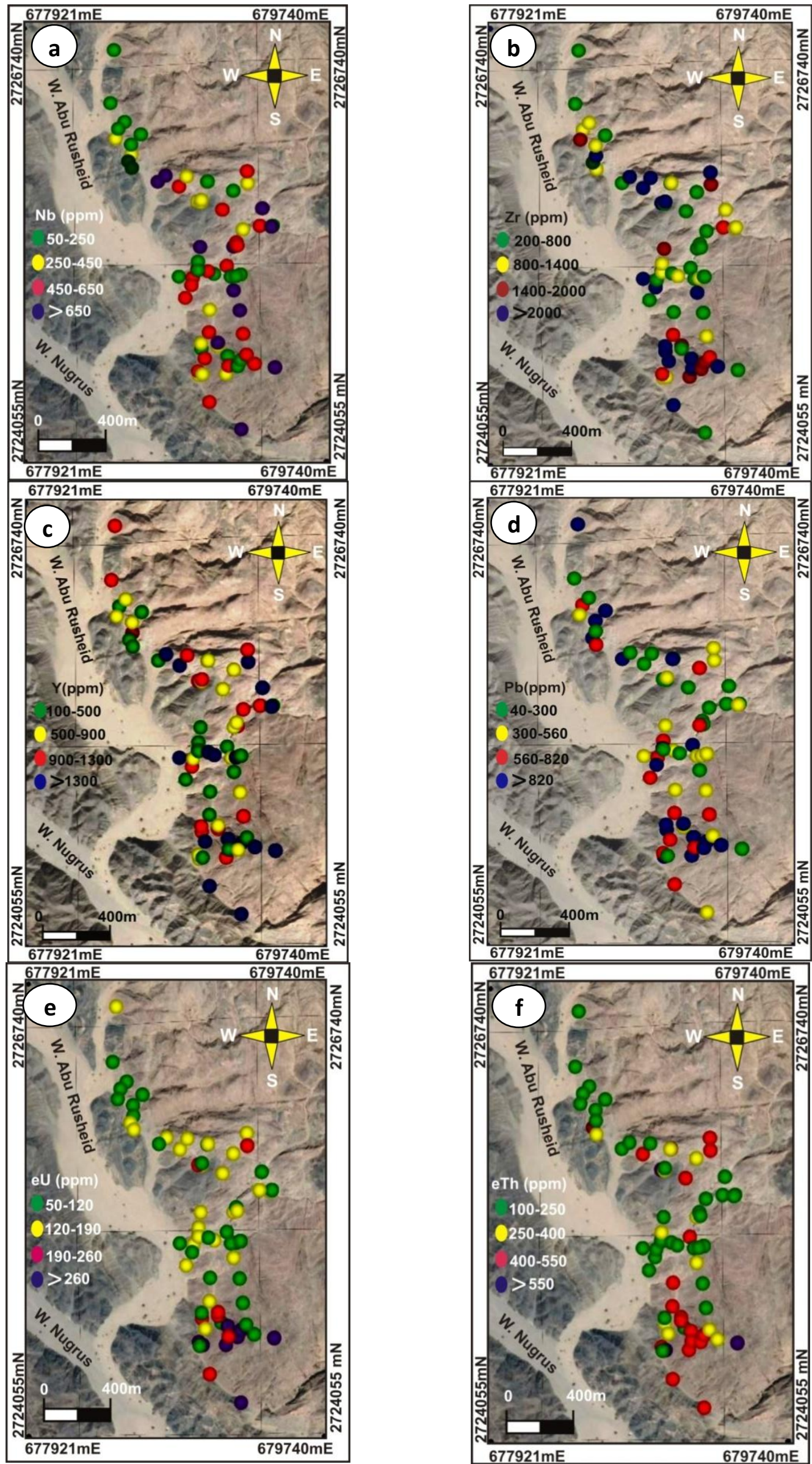

Figs.6. Distribution of some trace elements and eU, eTh (ppm) (in ppm) in Abu Rusheid pegmatite. 
Ibrahim, M.E et al.

\subsection{Rare Earth Elements}

The rare earth elements (REE) of the pegmatite and cataclasics (Table 3) were plotted in the normalized pattern (normalized to the chondrite values of Sun, (1980) (Figs. 7a -b). The REE contents have been upgraded from cataclastics rocks (134 ppm, on average) to pegmatites (342 ppm on average). Cataclastic samples exhibit fractionated REE patterns $[(\mathrm{La} / \mathrm{Yb}) \mathrm{N}=0.29$ on average $]$ and display relatively flat LREE $[(\mathrm{La} / \mathrm{Sm}) \mathrm{N}=2.52$ on average] with relatively enriched HREE $[(\mathrm{Gd} / \mathrm{Lu})$ $\mathrm{N}=0.66$ on average $]$ and negative Eu anomalies $\left(\mathrm{Eu} / \mathrm{Eu}^{*}=0.11\right)$. All the analyzed rocks show negative $\mathrm{Eu}$ anomaly, $\mathrm{Eu} / \mathrm{Eu}^{*}=0.01-0.28$ (Fig.7). Eu anomaly could be related to REE mobility (Boynton 1984) or due to Eu leaching by the volatile phase rich in fluorine, $\mathrm{H}_{2} \mathrm{O}$ and low temperature( $650^{\circ} \mathrm{C}$ )(Taylor et al. 1981 and Monecke et al. 2002) or attributed to sericitization (Alderton et al. 1980 and Bau, 1996). LREE is more enriched than the HREE in pegmatite ( $\Sigma$ LREE/ $/ \mathrm{HREE}=7.8$ ) and related to the presence of allanite-(Ce) and monazite-(Ce). Also, the presence of positive $\mathrm{Ce}$ anomaly $\left(\mathrm{Ce} / \mathrm{Ce}^{*}\right)$ ranging from 0.7 to 1.22 is attributed to occurrence of monazite- $(\mathrm{Ce})$ and to oxidizing conditions.
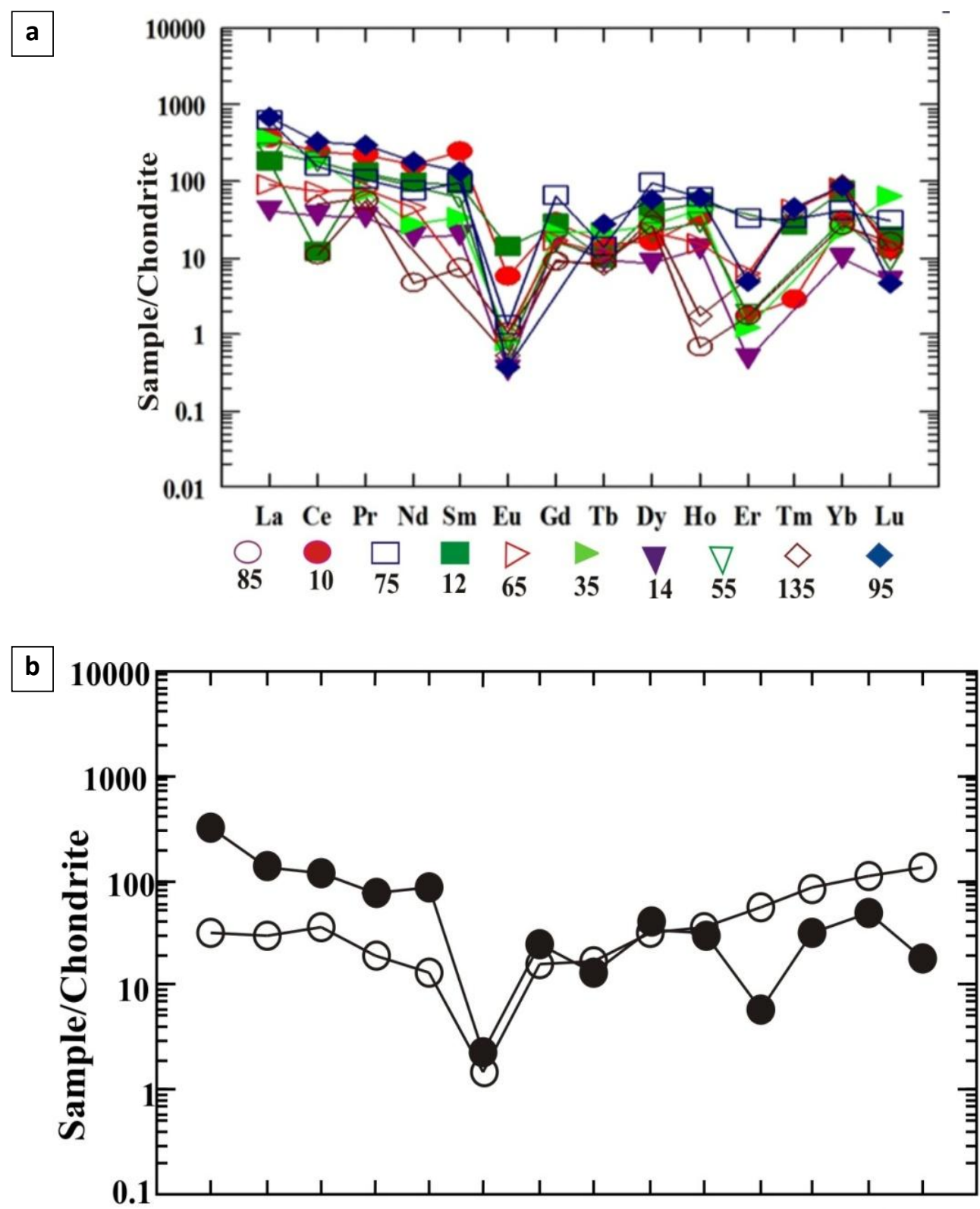

La Ce Pr Nd SmEu Gd Tb Dy Ho ErTmYb Lu

Cataclastic rocks

Uraniferous pegmatites

Fig.7. (A)Chondrite-normalized REE patterns for the Abu Rusheid pegmatite (B)Averages of chondritenormalized REE patterns of pegmatite and cataclastics, Abu Rusheid area, Normalizing values after Sun, (1980). 


\section{REE TETRAD EFFECT}

The tetrad effect manifests as a split of the chondrite normalized REE patterns into four segments called tetrads (first tetrad La-Ce-Pr-Nd; second tetrad, (Pm)-Sm-Eu-Gd; third tetrad, Gd-Tb-Dy-Ho; fourth tetrad, Er-Tm-Yb-Lu). Masuda et al. (1987) classified the tetrad effect into two different types, $\mathrm{M}$-and $\mathrm{W}$-type (M-type in solid sample as residues and $\mathrm{W}$-type in the interacting fluids as extract).

Masuda et al. (1994) and Minami and Masuda, (1997) presented a mathematical method to evaluate the degrees of lanthanide tetrad effects. Irber, (1999) proposed an alternative method of quantification to determine the intensity of the tetrad effect. In this case, only the first and the third tetrad are used for quantification of the tetrad effect and only samples with values of TE 1,3>1.10 are considered. The REE tetrad effect was mainly observed in late magmatic differentiation related to strong hydrothermal interactions or deuteric alteration (Jahn et al. 2001).

The calculated TE1,3 values for the REE patterns of the pegmatites are significantly lower than unity except two samples ranging from 0.59 to 1.1 (Table 3). The chonderite-normalized REEs patterns of the Abu Rusheid pegmatites show M-type tetrad effect similar to that quoted by Masuda et al. (1987).

Table3. Concentrations of rare earth elements of the pegmatites and cataclastics of the Abu Rusheid area

\begin{tabular}{|c|c|c|c|c|c|c|c|c|c|c|c|c|}
\hline Sample No. & 10 & $\mathrm{I} 2$ & 14 & 35 & 55 & 65 & 75 & 85 & 95 & I35 & $\begin{array}{c}\text { Average } \\
(\mathrm{n}=10)\end{array}$ & $\begin{array}{l}\text { Catac. } \\
(n=5)\end{array}$ \\
\hline La & 135.12 & 66.58 & 15.22 & 134.6 & 85.62 & 33.84 & 228.6 & n.d & 254.5 & n.d & 95.41 & 12 \\
\hline $\mathrm{Ce}$ & 233.08 & 111.3 & 33.89 & 181.6 & 173.25 & 72.83 & 149.5 & 10.29 & 307.0 & 47.01 & 131.97 & 29 \\
\hline Pr & 30.48 & 17.50 & 4.72 & 9.62 & \begin{tabular}{|l|}
16.47 \\
\end{tabular} & 10.55 & 14.63 & 7.61 & 39.74 & 8.38 & 15.97 & 5 \\
\hline Nd & 118.98 & 68.34 & 13.42 & 19.91 & n.d & 32.54 & 51.68 & 3.39 & 127.17 & n.d & 43.54 & 14 \\
\hline Sm & 57.59 & 21.32 & 4.53 & 7.67 & 14.10 & n.d & 21.75 & 1.64 & 31.70 & n.d & 16.03 & 3 \\
\hline $\mathbf{E u}$ & 0.50 & 1.23 & 0.03 & 0.07 & 0.053 & 0.094 & 0.11 & 0.09 & 0.033 & 0.046 & 0.23 & 0.13 \\
\hline Gd & 8.89 & 8.53 & 5.20 & 6.61 & 4.86 & 5.25 & 19.23 & 2.69 & 11.0 & 2.80 & 7.51 & 5 \\
\hline $\mathbf{T b}$ & 0.88 & 0.57 & 0.55 & 1.23 & 0.59 & 0.66 & 0.81 & 0.50 & 1.57 & 0.47 & 0.78 & 1 \\
\hline Dy & 6.14 & 14.68 & 3.29 & 10.01 & 8.05 & 8.34 & 35.58 & 9.79 & 21.60 & 12.35 & 12.98 & 12 \\
\hline Ho & 2.83 & 4.37 & 1.12 & 3.70 & 2.50 & 1.33 & 5.25 & 0.058 & 5.18 & 0.146 & 2.64 & 3 \\
\hline Er & 0.43 & n.d & 0.12 & 0.31 & 0.46 & 1.58 & 7.98 & 0.44 & 1.20 & 1.36 & 1.39 & 14 \\
\hline Tm & 0.10 & 0.92 & n.d & n.d & n.d & 1.55 & 1.16 & n.d & 1.63 & 1.48 & 0.68 & 3 \\
\hline $\mathbf{Y b}$ & 7.08 & 18.11 & 2.41 & 5.56 & 7.43 & 20.14 & 10.37 & 6.54 & 21.83 & 22.54 & 12.2 & 28 \\
\hline Lu & 0.48 & 0.71 & 0.19 & 2.40 & \begin{tabular}{|l|}
0.35 \\
\end{tabular} & \begin{tabular}{|l|}
0.55 \\
\end{tabular} & 1.19 & 0.62 & 0.18 & 0.48 & 0.72 & 5 \\
\hline$\sum$ REEs & 602.58 & 334.16 & 84.69 & 383.3 & 313.73 & 189.25 & 547.8 & 43.65 & 824.33 & 97.062 & 342 & 134 \\
\hline $\mathbf{E u} / \mathbf{E u} *$ & 0.07 & \begin{tabular}{|l|}
0.28 \\
\end{tabular} & 0.02 & 0.03 & \begin{tabular}{|l|}
0.02 \\
\end{tabular} & \begin{tabular}{|l|}
--- \\
\end{tabular} & 0.02 & 0.13 & 0.01 & --- & 0.06 & 0.1 \\
\hline $\mathrm{Ce} / \mathrm{Ce}^{*}$ & 0.8 & 0.7 & 0.97 & 1.22 & 1.12 & 0.93 & 0.77 & -- & 0.7 & -- & 0.859 & 1.1 \\
\hline TE1,3 & 0.68 & 0.686 & 0.86 & 0.93 & -- & 1.06 & 0.59 & -- & 1.1 & -- & 0.8 & 1.2 \\
\hline Sr/Eu & 320 & 107 & 3600 & 457 & 3415 & 202 & 1927 & 811 & 1455 & 2348 & -- & -- \\
\hline Y/Ho & 683 & 113 & 990 & 81 & 98 & 203 & 22 & 30897 & 337 & 1226 & -- & -- \\
\hline La/Gd & 15.2 & 7.8 & 2.9 & 20.4 & 17.6 & 6.4 & 11.9 & 0.0 & 23.1 & 0.0 & 12.7 & 2.4 \\
\hline ¿LREEs & 575.8 & 286.3 & 71.8 & 353.5 & 289.5 & 149.9 & 466.3 & 23.0 & 760.1 & 55.4 & 303.2 & 63.1 \\
\hline ¿HREEs & 26.83 & 47.89 & 12.8 & 29.82 & 24.24 & 39.4 & 81.57 & 20.63 & 64.19 & 41.626 & 39 & 71 \\
\hline$\sum$ LREEs/HREEs & 21.5 & 6.0 & 5.6 & 11.9 & 11.9 & 3.8 & 5.7 & 1.1 & 11.8 & 1.3 & 7.8 & 0.9 \\
\hline
\end{tabular}

$\mathrm{n}=$ Number of samples analyzed. Pegm.=pegmatites, Catac. $=$ cataclastics.

The tetrad effect is possibly caused by (1) fractional crystallization during igneous crystallization (Pan and Breaks, 1997), (2) fluid-melt interaction during crystallization of the silicate melt (Zhao et al. 2002, 2010), (3) hydrothermal alteration during hydrothermal fluid-rock interaction (Moneckeet al. 2007), and (4) weathering after granite formation (Takahashi et al. 2002).

\section{Spectrometric Prospecting}

Uranium and thorium tend to concentrate in the residual phases and enter the accessory minerals such as zircon, columbite-(Fe) and monazite-(Ce) (Rogers and Adams, 1969). Also, they may form minerals of their own such as thorium and uranium minerals. It has been shown that the accessory minerals and their sequence of crystallization play a major role in controlling the geochemical behavior of uranium and thorium in silicate melts (Simpson et al. 1979). The early crystallization of uranothorite would lead to significant U-enrichment in the residual fluids. On the other hand, the early crystallization of zircon and/or xenotime would lead to Th-enrichment in the residual fluids (Pagel, 1982). 
The eU and eTh contents in the pegmatite range from $50 \geq 250 \mathrm{ppm}$ and from $100 \geq 550 \mathrm{ppm}$ respectively. The average contents of eU and eTh (in ppm) in the pegmatite at khour Abalea ( $77 \mathrm{ppm}$ and $245 \mathrm{ppm}$ ) are higher than both southern and northern Abalea zone (83 ppmU and 128ppmTh) (36ppm U, 112ppm Th respectively). The strike-slip faults in Abalea zone played good pathways for transportation and redeposition of $\mathrm{U}-\mathrm{Th}$ mineralization.

The average eU $(83 \mathrm{ppm})$ content in pegmatite at the southern part of Abalea is more than the northern part (36 ppm) (Fig. 6e-f). The average of eU/eTh ratios in pegmatites greater than $0.4(0.42)$, so that they are fertile pegmatites (Hall and Walsh, 1969). The studied pegmatites have eTh/eU ratio averaging 1.69 indicating high effect of hydrothermal solution and affected by post-magmatic processes. Sminov, (1984) suggested that the low Th/U ratio (less than 3) is due to the effect of fluids carrying uranium mineralization. Cathelineaus and Holluger, (1987) stated that the uranium mineralization is affected by the different stages of alteration, these stages of leaching; mobility and redeposition of $U$ are affected by hydrothermal solutions and supergene fluids causing oxidation of the medium. Also, the presence of amazonite tends to enhance the content of $U$ and $T h$.

Radioactive minerals (metatorbernite, uranophane, B-uranophane, kasolite and thorite) in addition to zircon, monazite- $(\mathrm{Ce})$, xenotime- $(\mathrm{Y})$, fluorite, allanite- $(\mathrm{Ce})$ and columbite- $(\mathrm{Fe})$ are the main sources of the radioactivity in the studied pegmatites. The origin of the supergene secondary uranium minerals in pegmatites is mainly related to alteration of tetravalent primary U-minerals by the action of oxidized fluids and mobilization of uranium through pathways and redeposition along fracture planes and adsorbed on clay minerals and iron oxides as secondary minerals

\section{DisCUSSION AND CONCLUSION}

Two forms of pegmatite (segregations and dikes) have been intruded thecataclastic rocks at Abu Rusheid area. The pegmatites trending NNW-SSE with dip of about $10-30^{\circ}$ due WSW parallel to banding of the cataclastic country rocks. They shows a zonal distribution from the barren core to mineralized wall-zone in the metals; $\mathrm{Zr}, \mathrm{Nb}, \mathrm{Y}, \mathrm{Zn}, \mathrm{Pb}, \mathrm{Th}$ and $\mathrm{U}$. Albitization, chloritization, fluoritization and silicification are the common alteration processes in pegmatites due to the effect of hydrothermal solution. The zoned pegmatite dikes characterized by cavities and vugs. These vugs are common in quartz and decrease in feldspars and could be considered as physical traps for rare metal mineralization.

On the basis of mineralogical and chemical characteristics, the cataclastic rocks are derived from Stype magma. Therefore, during late stage of anatexis silica is predominant phase than alumina due its higher mobility (Tracy and McLellan, 1985). Quartzite was formed at the late stage of cataclastic rocks without banding or gneissosity or even intruded by pegmatites. Low $\mathrm{CaO}$ content and enrichment of HFSE ( $\mathrm{Nb}, \mathrm{Zr}, \mathrm{Y}, \mathrm{U}, \mathrm{Th}$ ) in cataclastic rocks, suggest that they are primarily derived from felsic source.

LCT- pegmatite type suit are enriched in $\mathrm{Li}, \mathrm{Cs}$, Ta and B and derived from undepletet upper-crustal lithological suffering their first anatectic event, which mobilizes the most volatile component into low-temperature, low-percentage melts. NYF-type suite is characterized by; 1) high economic concentration of $\mathrm{Zr}, \mathrm{Nb}, \mathrm{Y}, \mathrm{Zn}, \mathrm{Pb}$, Th and $\mathrm{U}, 2$ ) have the geochemical signature of A-granites and 3) may be derived by melting of depleted lower-crustal sources. The high $\mathrm{Rb} / \mathrm{Sr}, \mathrm{Ba} / \mathrm{Sr}, \mathrm{K}_{2} \mathrm{O} \%$ and moderate $\mathrm{Rb}$ and low $\mathrm{Sr}$ content exclude derivation of the pegmatites from basic parentage (Rogers and Greenberg, 1990). The studied Abu Rusheid pegmatites have low-CaO content (1\% on average), high $\mathrm{Fe} / \mathrm{Mg}$ ratio (5.9 on average), peraluminous, A-type post-orogenic tectonic setting (Ragab, 2003) and equivalent to NYF- pegmatite type.

The REE contents have been upgraded from cataclastics rocks (134 ppm on average) to pegmatites (342 ppm, on average). Cataclastic samples exhibit relatively enriched HREE [ $(\mathrm{Gd} / \mathrm{Lu}) \mathrm{N}=0.66$ on average]. The pegmatites have clear enrichment of LREE relative to HREE as indicate by the presence of zircon, allanite-(Ce) and monazite-(Ce). Also, the presence of positive $\mathrm{Ce}$ anomaly $\left(\mathrm{Ce} / \mathrm{Ce}^{*}\right)$ ranging from 0.7 to 1.22 is attributed to occurrence of monazite- $(\mathrm{Ce})$ and to oxidizing conditions. Hydrothermal alteration during post magmatic stages is also identified through the development of M-type tetrad effect in the REE pattern of pegmatite.

The rare metals enrichment in the study area are formed due to the subsequent processes; including the ascending hydrothermal solutions (alkaline followed by acidic hydrothermal solutions), with 
further contribution of the descending acidic meteoric water; supergene enrichment processes. The origin of uranium appears to be closely associated with the rare metals mineralization and may be reflects readily their intimate coherence. The later conclusion is compatible with Ibrahim et al. (2004) on cataclastic rocks and could be related to the same origin.

Uranium bearing pegmatitic segregation in parallel to cataclastics banding may be formed before segregation of silica-rich melt and forming quartzite during culmination stage of cataclastic rocks (protomylonite, mylonite and ultramylonite). According to Jahns and Burnham (1969), early appearance of vapour phase during crystallisation history can segregate and form large pegmatite but late stage of saturation can only permit to form small segregation parallel to the banding of cataclastic rocks. Similarly highly mobile elements like uranium, probably derived from fertile host rocks (cataclastic rocks), can easily be saturated in vapour charged silica-rich pegmatitic fluids. With change of physico-chemical conditions of the rock, $\mathrm{Zr}, \mathrm{Nb}, \mathrm{Y}, \mathrm{Th}$ and $\mathrm{U}$ - minerals are crystallized syn-magmatically. Abu Rusheid area could be considered as low grade for $\mathrm{U}, \mathrm{Th}, \mathrm{Nb}$ ores (Figs. 8) and moderate grade for $\mathrm{Zr}$ ore.
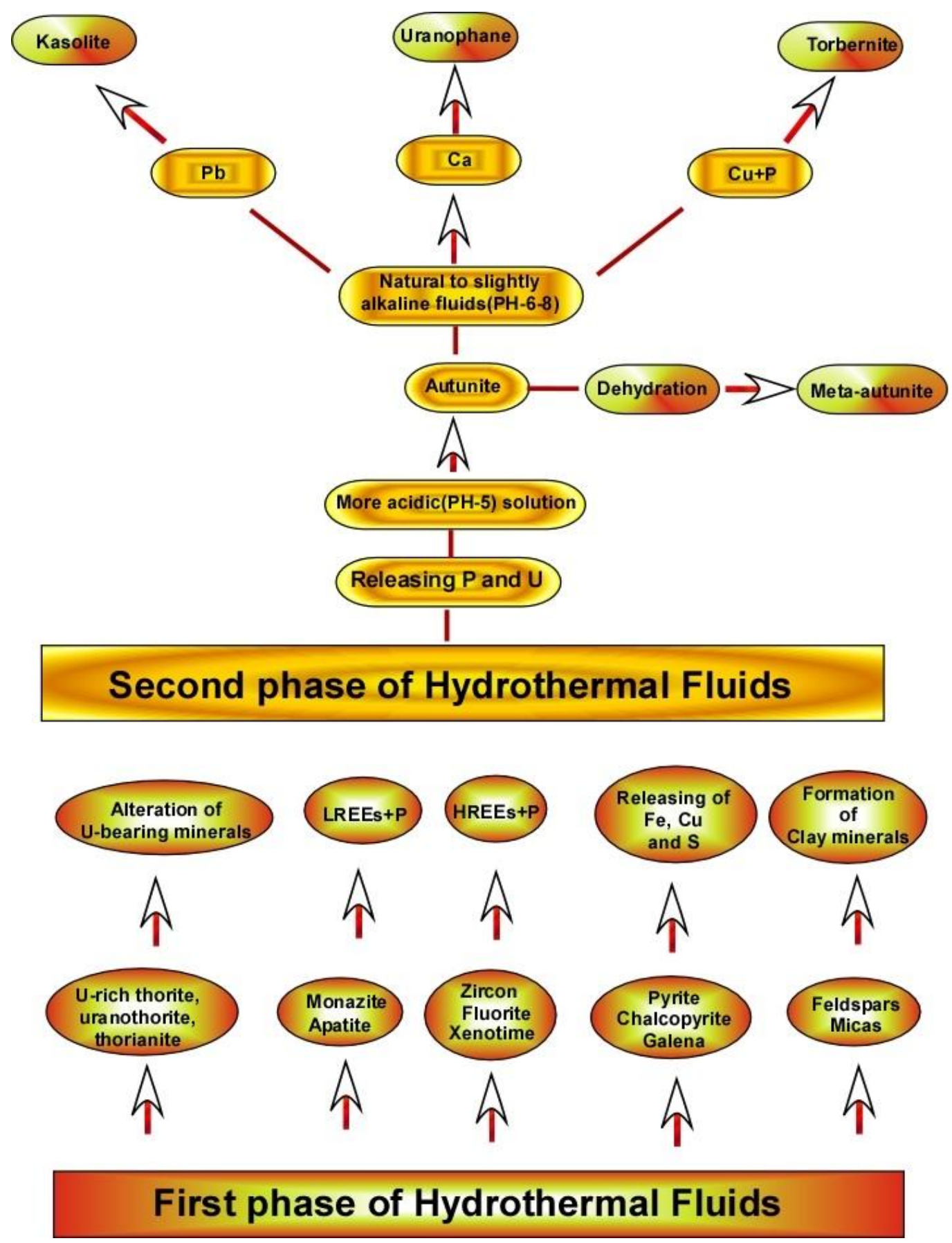

Fig.8. Paragenetic model of the uranyl minerals from the Abu Rusheid area with major modification after (Ibrahim et al., 2004 and Dawood, 2010) 


\section{ACKNOWLEDGEMENT}

The authors sincerely thank Dr. Mohamed Rasheid, NMA, Cairo, Egypt for his assistance in field sampling.

\section{REFERENCES}

[1] Alderton, D.H.M., Pearce, J.A. and Potts, P.J. (1980): Rare earth element mobility during granite alteration: Evidence from southwest England. Earth Planet. Sci. Lett., 49, pp 149-165.

[2] Assaf, HS, Ibrahim ME, Zalata AA, El-Metwally AA, Saleh GM (2000):Polyphase folding in Nugrus-Sikait area south Eastern DesertEgypt. JKAW: Earth Sci 2000(12):1-16

[3] Bau, M. (1996): Controls on the fractionation of isovalent trace elements in magmatic and aqueous systems: evidence from $\mathrm{Y} / \mathrm{Ho}, \mathrm{Zr} / \mathrm{Hf}$, and lanthanide tetrad effect. Contrib. Mineral. Petrol. 123, 323-333.

[4] Boynton, W.V. (1984): Geochemistry of the rare earth elements: meteorite studies. In: derson, P. (ed.), Rare earth element geochemistry, Elsevier, 63-114

[5] Brown, G.C., Thorpe, R.S. and Webb, P.C. (1984): The geochemical characteristics of Granitoid in contrasting areas and comments on magma sources. Jour. Geol. Soc. London, v.141, pp.413426.

[6] Cathelineaus, M. and Holluger, P. (1987):Polyphasemetallogenesis of hydrothermal map uranium veins from the southern Armoricanmassife, France. Proc. Int. Mtg, Nacy, P. 212-217.

[7] Cerny P, Ercit TS (2005): The classification of granitic pegmatites revisited. Canadian Mineralogist 43: 2005-2026

[8] Černy, P. (1991): Rare-element granitic pegmatites. II. Regional to global environments and petrogenesis. Geosci. Can. 18, 68-81.

[9] Dawood. Y. H. (2010): Mineral Chemistry and Genesis of Uranyl Minerals Associated with Psammitic Gneisses, Abu Rusheid Area, South Eastern Desert of Egypt. JKAU: Earth Sci., Vol. 21, No. 1, pp: 137-169.

[10] Hassan MA (1964): Geology and petrographical studies of the radioactive minerals and rocks in Wadi Sikait-Wadi El Gemal area. Eastern Desert, U. A. R: M. Sc. Thesis Faculty of Science, CairoUniv.1964, 165

[11] Hall, A. and Walsh,J.N., (1969): Rabid method for the determination of fluorine in silicate rocks and minerals. Anal Chem. Acta, 54, 341-342

[12] Ibrahim, M. E. Saleh, G. M., Ibrahim, I. H., Azab, M. S., Khamies, A. A., Oraby, F., Abu ElHassan, E. A. and Ragab, A. A. (2004): Geologic and ground spectrometric prospecting of the Abu Rusheid-Sikait shear zones, South Eastern Desert, Egypt. Seventh Arab Conference on the Peaceful Uses of Atomic Energy, Sanaa, Yamen.

[13] Ibrahim, M. E. Saleh, G. M., Hassan, M. A., El Tookhi and Rashed M. A. (2007): Geochemistry of lamprophyres bearing uranium mineralization, Abu Rusheid area, south Eastern Desert, Egypt. The 10th Inter. Min., petrol., Metall. Engin, Conf., Assuit Univ., 6-8 March.

[14] Ibrahim, M. E. Saleh, G. M., Rashed, M, Watanabe, K. and Motomura, Y. (2006): Base Metal Mineralization in a lamprophyre dyke, South Eastern Desert, Egypt. The 6th International.Conference on the Geology of the Middle East, Al-Aian, United Arab Emirates. P. 14-25.

[15] Ibrahim, M.E. K. Watanabe, G.M. Saleh and W. S. Ibrahim (2015): Abu Rusheid lamprophyre dikes, South Eastern Desert, Egypt: as physical-chemical traps for REEs, Zn, Y, U, Cu, W, and Ag. Arab J Geosci (2015) 8:9261-9270

[16] Ibrahim, M.E., Saleh, G.M., Dawood, N.A. and Aly, G.M. (2010): Ocellar lamprophyre dykebearing polymineralization at Wadi Nugrus, Eastern Desert of Egypt: mineralogy and geochemical implications. J Geol Min Res 2(4):74-86

[17] Irber, W. (1999): The lanthanide tetrad effect and its correlation with $\mathrm{K} / \mathrm{Rb}, \mathrm{Eu} / \mathrm{Eu}{ }^{*}, \mathrm{Sr} / \mathrm{Eu}$, $\mathrm{Y} / \mathrm{Ho}$, and $\mathrm{Zr} / \mathrm{Hf}$ of evolving eraluminous granite suites. GeochimicaetCosmochimicaActa 63 , 489-508.

[18] Jahn, B.-M., Wu, F., Capdevila, R., Martineau, F., Zhao, Z., and Wang, Y. (2001): Highly evolved juvenile granites with tetrad REE patterns: the Woduhe and Baerzhe granites from the Great Xing' an Mountains in NE China. Lithos 59, 171-198. 
[19] Jahns, R.H., and Burnham, C. Wayne (1969): Experimental studies of pegmatite genesis: I. A model for the derivation and crystallization of granitic pegmatites, Economic Geology, 64, 843864.

[20] Masuda A, Matsuda N, Minami M, Yamamoto H (1994): Approximate estimation of the degree of lanthanide tetrad effect from precise but partially void data measured by isotope dilution and an electron configuration model to explain the tetrad phenomenon. Proc JpnAcad 70B:169-174

[21] Masuda, A., Kawakami, O., Dohomoto, Y., andTakenaka, T. (1987): Lanthanide tetrad effects in nature: two mutually opposite types, W and M. Geochemical Journal 21, 119-124.

[22] Minami M, Masuda A (1997): Approximate estimation of the degree of lanthanide tetrad effect from the data potentially involving all lanthanides. Geochem J 31:125-134

[23] Monecke, T., Dulski, P., and Kempe, U. (2007): Origin of convex tetrads in rare earth element patterns of hydrothermally altered siliceous igneous rocks from the Zinnwald Sn-W deposit, Germany. Geochimi.et Cosmochimi. Acta, 71, 335-353.

[24] Monecke, T., Kempe, U., Monecke, J., Sala, M., and Wolf, D. (2002): Tetrad effect in rare earth element distribution patterns: a method of quantification with application to rock and mineral samples from granite-related rare metal deposits. Geochim.Cosmochim. Acta, vol. 66, pp 11851196.

[25] Pagel, M. (1982): The mineralogy and geochemistry of uranium, thorium and rare elements in two radioactive granites of Vosages, France. Min.Mag. 46/339:149-161.

[26] Pan, Y., and Breaks, F.W. (1997): Rare-earth elements in fluorapatite, Separation Lake area, Ontario: evidence for S-type granite-rare-element pegmatite linkage. Canadian Mineralogist 35, 659-671.

[27] Pearce, J. A., Harris, N. B. W., and Tindle, A. J. (1984): Trace element discrimination diagrams for the tectonic interpretation of granitic rocks. J. Petrol., 25, 956-83.

[28] Ragab, A. (2003): Geochemistry and radioactivity of mineralized pegmatite from Abu Rusheid area, south Eastern desert, Egypt, earth Sci.Vol.22. No.2, 99-130

[29] Rogers, J. J. W. and Adams, J. A. S., (1969): Uranium and thorium, In: K. H. Wedepohl (ed.), Handbook of geochemistry. Berlin, Springer-Verlag, Vol.11 3, 92-B-1 to 92-0-8 and 90-Bb-1 to 90-00-5, $201 \mathrm{P}$.

[30] Rogers, J.J.W., Greenberg, J.K., (1990): Late-orogenic, post-orogenic and anorogenic granites: distinction by major-element and trace-element chemistry and possible origins. Journal of Geology 98 (3), 291 \pm 309.

[31] Saleh GM (1998): The potentiality of uranium occurrences in Wadi Nugrus area, south Eastern Desert, Egypt. Ph. D. Thesis Mans. Univ., 171

[32] Simmons, Wm. B. \& Webber, K.L. (2008): Pegmatite genesis: state of the art. European Journal of Mineralogy , 20: 421-438

[33] Simpson, P.R., Brown, G. C., Plant, J. and Ostle,D.( 1979): Uranium mineralization and granite magmatism in the British Isles. In: Bowie, S.H.U., Fyfe, W.S., Ostle, D., plant, J and Simpson, P. R.(eds.). Theoretical and practical aspects of uranium geology, Trans. Roy.Soc., London, A.291, pp.385-412.

[34] Sminov, S.D. (1984): U-Th-REE mobility in granitic environments at the hydrothermal stage. IAEA, Vienna, 215-246.

[35] Stern RJ and Hedge CE (1985):Geochronologic and isotopic constraints on Late Precambrian crustal evolution in the Eastern Desert of Egypt. Am Jour Sci 285: 97-127.

[36] Sun, S.S. (1980): Lead isotopic study of young volcanic rocks from mid-ocean ridges, ocean islands and island arcs. Philosophical Transactions of the Royal Society of London, Series A ,V.297, p.409-445.

[37] Takahashi, Y., Yoshida, H., Sato, N., Hama, K., Yusa, Y., and Shimizu, H. (2002): W- and M type tetrad effects in REE patterns for water-rock systems in the Tono uranium deposit, central Japan. Chemical Geology 184, 311-335.

[38] Taylor, S.R., Arculus, R., Perfit, M.R. and Johnson, R.W. (1981): Island arc basalts. In: Merrill RB, Ridings R (eds) Basaltic volcanism on the terrestrial planets, 193-213. Pergamon, New York 
[39] Tracy, R. J. \& McLellan, E. L. (1985): A natural example of the kinetic controls of compositional and textural equilibration. In: Thompson, A. B. \&Rubie, D. C. (eds) Metamorphic Reactions; Kinetics, Textures, and Deformation. Advances in Physical Geochemistry 4, 118-13.

[40] Viswanathan, S. (1993): Critical element ratio maps of granitic and migmatitic areas (CERMOGAMA): A supplement to radiometric and magnetic maps (ASTRAMA). Workshop on 'High Sensitivity Airborne Radiometric and Magnetic Surveys' AMD, Hyderabad, pp.1-7.

[41] Wang, R.C., ZHAO, G.T., Lu, J.J., CHEN, X.M., XU, S.J. and Wang, D.Z. (2000): Chemistry of Hf-rich zircon from the loashan I- and A-type granites, Eastern China, Mineral-Magaz., Vol. 64(5), pp. 867-877.

[42] Whalen, J .B., Currie, K .L. \& Chappell, B .W. (1987): A-type granites: geochemical characteristics, discrimination and petrogenesis. Contrib. Mineral. Petrol. 95, 407-419.

[43] Williams-Jones, A.E.(2002): Hydrothermal fluids in NYF pegmatites, South Platte, Colorado preliminary insights from LA-ICP-MS analysis of quartz- and fluorite-hosted fluid inclusions. Eighth Pan-American Conf. on Research on Fluid Inclusions, Program with Abstr., 25-27.

[44] Zhao, Z.-H., Bao, Z., Qiao, - and W.Y.-L. (2010):A peculiar composite M- and W-type REE tetrad effect: evidence from the Shuiquangou alkaline syenite complex, Hebei Province, China. Chinese Science Bulletin 55, 2684-2696.

[45] Zhao, Z.-H., Xiong, X.-L., Han, X.-D., Wang, Y.-X., Wang, Q., Bao, Z.-W., and Jahn, B.M.(2002): Controls on the REE tetrad effect in granites: evidence from the Qianlishan and Baerzhe granites, China. Geochemical Journal 36, 527-543. 